by the challenge of unknown long-term benefits (eg, survival and quality of life, including from spinal cord injury) of more aggressive root or arch operations. The central question of acute aortic dissection surgery as far as extent of repair remains: Is the added risk of more definitive repairs at the index procedure justified to influence better long-term survival (as noted)? Only a 4-arm, randomized trial with a comparison of conservative versus aggressive arch repair or conservative versus aggressive aortic valve surgery, would better inform us. Even then, conservative surgery may have better outcomes at 30 days but not better long-term outcomes. True benefits can only be concluded following restricted means analysis of late survival benefits comparing arm groups, say at 5 years, if not 10 years.

Like so many unanswered questions, it will remain a mystery that will unlikely be definitively answered in our lifetimes. If the authors can access long-term follow-up data from this valuable data set, additional conclusions may be imputed supporting a universal theory of best cardiac surgery practice, particularly for aortic dissection.

\section{References}

1. Okita Y, Kumamaru H, Motomura N, Miyata H, Takamoto S. Current status of open surgery for acute type A aortic dissection in Japan. J Thorac Cardiovasc Surg. 2022;164:785-94.e1.

2. Ghoreishi M, Sundt TM, Cameron DE, Holmes SD, Roselli EE, Pasrija C, et al. Factors associated with acute stroke after type A aortic dissection repair: an analysis of the Society of Thoracic Surgeons National Adult Cardiac Surgery database. J Thorac Cardiovasc Surg. 2020;159:2143-54.

3. Rosinski BF, Idrees JJ, Roselli EE, Germano E, Pasadyn SR, Lowry AM, et al. Cannulation strategies in acute type A dissection repair: a systematic axillary artery approach. J Thorac Cardiovasc Surg. 2019;158:647-59.e5.

4. Lee TC, Kon Z, Cheema FH, Grau-Sepulveda MV, Englum B, Kim S, et al. Contemporary management and outcomes of acute type A aortic dissection: an analysis of the STS adult cardiac surgery database. J Card Surg. 2018;33:7-18.

5. Hussain ST, Svensson LG. Surgical techniques in type A dissection. Ann Cardiothorac Surg. 2016;5:233-5.

6. Roselli EE, Idrees JJ, Bakaeen FG, Tong MZ, Soltesz EG, Mick S, et al. Evolution of simplified frozen elephant trunk repair for acute DeBakey type I dissection: midterm outcomes. Ann Thorac Surg. 2018;105:749-56.

7. Crawford ES, Kirklin JW, Naftel DC, Svensson LG, Coselli JS, Safi HJ. Surgery for acute dissection of ascending aorta. Should the arch be included? J Thorac Cardiovasc Surg. 1992;104:46-59.

8. Svensson LG. Are we there yet? Emerging milestones in aortic dissection care. J Am Heart Assoc. 2019;8:e012402.

9. Svensson LG, Crawford ES, Hess KR, Coselli JS, Safi HJ. Dissection of the aorta and dissecting aortic aneurysms. Improving early and long-term surgical results. Circulation. 1990;82:IV24-38.

\title{
Commentary: Short-term outcomes following type A repair: A small step or a giant leap?
}

\section{Joshua C. Grimm, MD, ${ }^{\mathrm{a}}$ and Arman Kilic, $\mathrm{MD}^{\mathrm{b}}$}

With the continued growth of robust, acute type A aortic dissection databases, the preponderance of outcomesbased analyses in the literature over the past decade has increased substantially. In a recent examination of the Japanese experience published in the Journal, Okita and

From the ${ }^{\mathrm{a}}$ Division of Cardiac Surgery, The University of Pennsylvania School of Medicine, Philadelphia; and ${ }^{\mathrm{b}}$ Division of Cardiac Surgery, The University of Pittsburgh Medical Center, Pittsburgh, Pa.

Disclosures: Dr Kilic reported Medtronic (Advisory Board). Dr Grimm reported no conflicts of interest.

The Journal policy requires editors and reviewers to disclose conflicts of interest and to decline handling or reviewing manuscripts for which they may have a conflict of interest. The editors and reviewers of this article have no conflicts of interest.

Received for publication Oct 6, 2020; revisions received Oct 6, 2020; accepted for publication Oct 7, 2020; available ahead of print Oct 17, 2020.

Address for reprints: Arman Kilic, MD, University of Pittsburgh Medical Center, 200 Lothrop St, Suite C-700, Pittsburgh, PA 15213 (E-mail: kilica2@upmc.edu).

J Thorac Cardiovasc Surg 2022;164:796-7

$0022-5223 / \$ 36.00$

Copyright $₫ 2020$ Published by Elsevier Inc. on behalf of The American Association for Thoracic Surgery

https://doi.org/10.1016/j.jtcvs.2020.10.028

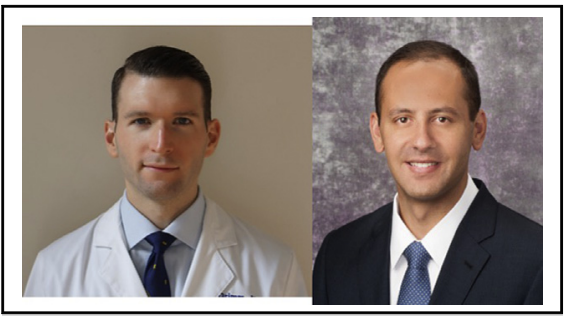

Joshua C. Grimm, MD, and Arman Kilic, MD

CENTRAL MESSAGE

Short-term results following

repair of acute type $A$ aortic

dissections have improved

dramatically. It is imperative, however, to understand the long-

term effects of intraoperative

decision making.

colleagues $^{1}$ reviewed nearly 30,000 dissection patients who underwent repair over a 6-year period. Although the authors' conclusions largely mirror a number of similar 
studies in regard to the impact of patient- and disease-specific risks on surgical outcomes, one of their most intriguing findings is more subtle. Namely, the inhospital mortality, although consistent throughout the study period, was impressively low at less than $11 \%$.

The surgeons contributing to this registry should be commended on these outstanding results in an especially challenging cohort, but is reporting short-term outcomes without consideration of the long-term effects of surgical decision-making sufficient? The authors acknowledge 2 critical distinctions that could have conflicting implications on late valve and/or aortic reinterventions. The incidence of formal root procedures, whether valve-sparing or a conventional composite replacement, was exceedingly low $(5 \%)$ when compared with several other large series $(25 \%-35 \%))^{2,3}$ The ultimate influence of this intraoperative decision on short- and intermediate-term outcomes is controversial $^{4}$ but could adversely affect long-term rates of reoperation. ${ }^{5}$ Conversely, the use of a more extensive arch replacement, which has been advocated by many groups in China and Japan in particular, occurred in upwards of $30 \%$ of patients. The strategy of a total arch solution is admittingly aggressive by their own account, particularly if a hard indication for such an approach is lacking as the long-term data following hemiarch alone are acceptable. ${ }^{6}$ Furthermore, as a frozen elephant trunk was employed regularly in this series (14\%), the additional benefit of a total arch replacement over transverse hemiarch is disputable.
While outcomes following surgical repair of acute type A dissections are driven by multiple factors and risk adjustment is likely inadequate as it represents a complete aortic catastrophe, a thorough evaluation of late events is critical. While many of the national and international databases provide ample numbers to enable a meaningful analysis of perioperative morbidity and mortality, the long-term influence of operative decisions is dependent on comprehensive follow-up.

\section{References}

1. Okita Y, Kumamaru H, Motomura N, Miyata H, Takamoto S. Current status of open surgery for acute type A aortic dissection in Japan. J Thorac Cardiovasc Surg. 2022;164:785-94.e1.

2. Ghoreishi M, Sundt TM, Cameron DE, Holmes SD, Roselli EE, Pasrija C, et al Factors associated with acute stroke after type A aortic dissection repair: an analysis of the Society of Thoracic Surgeons national adult cardiac surgery database. $J$ Thorac Cardiovasc Surg. 2020;159:2143-54.e3.

3. Evangelista A, Isselbacher EM, Bossone E, Gleason TG, Eusanio MD, Sechtem U, et al. Insights from the international registry of acute aortic dissection: a 20-year experience of collaborative clinical research. Circulation. 2018;137:1846-60.

4. Di Eusanio M, Trimarchi S, Peterson MD, Myrmel T, Hughes GC, Korach A, et al. Root replacement surgery versus more conservative management during type A acute aortic dissection repair. Ann Thorac Surg. 2014;98:2078-84.

5. Chiu P, Trojan J, Tsou S, Goldstone AB, Joseph Woo Y, Fischbein MP. Limited root repair in acute type A aortic dissection is safe but results in increased risk of reoperation. J Thorac Cardiovasc Surg. 2018;155:1-7.e1.

6. Kim JB, Chung CH, Moon DH, Ha GJ, Lee TY, Jung SH, et al. Total arch repair versus hemiarch repair in the management of acute DeBakey type I aortic dissection. Eur J Cardiothorac Surg. 2011;40:881-7.

7. Vallabhajosyula P, Gottret JP, Robb JD, Szeto WY, Desai ND, Pochettino A, et al. Hemiarch replacement with concomitant antegrade stent grafting of the descending thoracic aorta versus total arch replacement for treatment of acute DeBakey I aortic dissection with arch tear. Eur J Cardiothorac Surg. 2016;49:1256-61. 